\title{
Mineralogical and geochemical characterization of hydrocarbon microseepage-induced sediments in part of Assam-Arakan Fold Belt, Cachar area, NE India
}

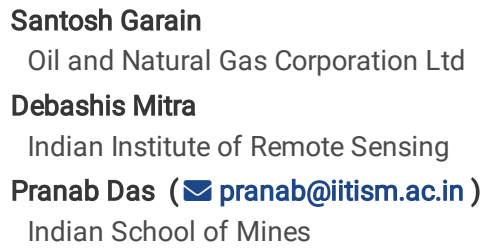

\section{Research article}

Keywords: Hydrocarbon, microseepage, geochemical, alterations, sediments, reflectance spectroscopy, XRD, XRF, trace elements

Posted Date: April 30th, 2020

DOI: https://doi.org/10.21203/rs.3.rs-25262/v1

License: @ (i) This work is licensed under a Creative Commons Attribution 4.0 International License. Read Full License

Version of Record: A version of this preprint was published at Journal of Earth System Science on February 10th, 2022. See the published version at https://doi.org/10.1007/s12040-022-01894-1. 


\section{Abstract}

Long term hydrocarbon microseepages create a reducing environment on the surface rocks and sediments, which induces an array of mineralogical alterations. Among these alterations, the reduction of ferric iron minerals to ferrous iron minerals and precipitation of clay and carbonates are significant. Several studies have been carried out to characterize these hydrocarbon induced rocks/sediments. Almost all these studies have been carried out for arid to semi-arid climatic regions. The present study attempts to characterize the geochemical properties of the hydrocarbon induced sediments in part of AssamArakan Fold Belt (AAFB), NE India characterized by heavy rainfall.

Reflectance spectroscopy, X-ray diffraction (XRD), X-ray fluorescence (XRF) and inductively coupled plasma emission - mass spectrometry (ICP-MS) studies have been carried out on the sediments. The reflectance spectroscopy reveals that microseepage-induced sediments have higher clay content and lesser ferric iron mineral content. Geochemical indices also suggest that the hydrocarbon-affected sediments are relatively more altered than the unaffected ones. Studies of trace element patterns indicate that the hydrocarbon-induced sediments are enriched in average $\mathrm{Be}, \mathrm{V}, \mathrm{Cu}, \mathrm{Zn}, \mathrm{Ga}, \mathrm{Zr}$, and Mo and are depleted in $\mathrm{Li}$, $\mathrm{Cr}$, $\mathrm{Co}$, $\mathrm{Ni}, \mathrm{Rb}, \mathrm{Sr}, \mathrm{Sc}$, and $\mathrm{Y}$. The normalized rare earth element (REE) distribution patterns are the same for both the microseepage affected and unaffected sediments though the microseepage-induced sediments are slightly depleted in the REEs. The present study, thus, points out that the hydrocarbon microseepage-induced alterations are also evident in the high precipitation terrains though the alteration levels are less pronounced than that of the arid to semi-arid climatic regions due to abundant surface and groundwater which mobilize the minerals/elements from the microseepage system and tries to homogenize the compositions.

\section{Introduction}

Hydrocarbons accumulated in the subsurface reservoirs are needed to be capped by some impervious rocks to prevent their escaping. However, no cap rock is perfectly impervious in nature, and trace amounts of hydrocarbons move vertically or near vertically to the Earth's surface through the micro-pores or fractures in the cap rocks in slowly in the form of hydrocarbon microseepages. The microseepages are invisible but pervasive in comparison to the hydrocarbon macroseepages, which are visible but small (point) in the areal extent (Link 1952; Price 1986; Tedesco 1995; Schumacher 1999; Etiope 2015). The occurrence of hydrocarbon microseepages helps us in detecting subsurface hydrocarbon reservoirs directly beneath them, though the depth and commerciality of the reservoirs cannot be ascertained. Despite the very small amount of hydrocarbons moving as microseepages, their long term migrations have significant effects on the surface rocks and sediment covers. It has been observed that the migrating hydrocarbons are oxidized by the bacteria, and the $\mathrm{E}_{\mathrm{h}}-\mathrm{p}^{\mathrm{H}}$ condition of the sediment cover is changed to a reducing environment (Schumacher 1996; Saunders et al. 1999; Warren 2012, Asadzadeh et al. 2017). The reducing condition causes a series of geochemical changes in surface rocks/sediment covers. Among the various geochemical changes, the following three are more prominent:

a) Bleaching of red beds: Red beds or rocks having a higher amount of ferric iron minerals become bleached due to the transformation of ferric iron (Fe ${ }^{+3}$ ) minerals to ferrous iron $\left(\mathrm{Fe}^{+2}\right.$ ) minerals (Donovan 1974; Segal et al. 1984, 1986, Schumacher 1996). The developed ferrous iron minerals may precipitate in situ or mobilize to other places by the groundwater. Thus, the original parent rock becomes deficient in ferric iron minerals and may or may not become enriched in ferrous iron minerals. The common ferric iron minerals involved in the hydrocarbon microseepage alterations are hematite and goethite, and the common ferrous minerals developed are magnetite, pyrite, and siderite.

b) Precipitation of clay minerals: The dominance of bacterial action in the hydrocarbon microseepage environment enhances the decomposition of feldspar and mica to form clay minerals (Saunders et al. 1993a; Schumacher 1996; Warren 2012). Though the most important clay mineral is the kaolinite, other clay minerals such as illite, montmorillonite may also form.

c) Formation of carbonate minerals: The formation of $\mathrm{CO}_{2}$ during the decomposition of hydrocarbons reacts with the $\mathrm{CaO}$ present in the parent rocks to form carbonate minerals (Donovan 1974; Saunders et al. 1999; Schumacher 1996). Calcite and dolomite are the most common carbonate minerals in the hydrocarbon microseepage environment. However, the formation of these minerals depends upon the availability of calcium in the parent rocks.

Lots of studies have been carried out to characterize the diagenetic changes associated with hydrocarbon microseepages. Almost all these studies have been carried out on the in-situ rocks of the petroleum basins occurring in the arid to semi-arid climatic conditions. However, many of the petroliferous sedimentary basins of the world are located in the heavily precipitated areas and are covered by sediments. The geochemical characterization of the hydrocarbon microseepage-induced sediments of such basins has not been studied in great detail. The present study is a deliberate attempt to characterize the mineralogical and geochemical properties of the sediments affected by hydrocarbon microseepages in part of Assam-Arakan Fold Belt (AAFB) basin, NE India characterized by heavy precipitation.

\section{Study Area}

The study area chosen is a part of a known petroliferous basin- Assam-Arakan Fold Belt (AAFB) located in the northeastern part of India. The study area lies to the southern part of the basin and extends in and around Cachar district of Assam, India. The study area is bounded by the latitude $24^{0} 31^{\prime} \mathrm{N} / 24^{0} 57^{\prime} \mathrm{N}$ and longitude $92^{0} 37^{\prime} \mathrm{E} / 93^{\circ} 07^{\prime} \mathrm{E}$ covering an area of about $2400 \mathrm{~km}^{2}$ (Fig. 1a). A false colour composite (FCC) image depicting the distribution of bare lands and vegetational areas of the study area formed by the bands 5-4-3 of the Landsat 8 image in the RGB space is also represented in Fig. $1 \mathrm{~b}$. The climate of the area is tropical humid with the dominance of rainy seasons and short dry winter season. The average annual rainfall is very high (about $3100 \mathrm{~mm} / \mathrm{year}$ ). The mean temperature during winter ranges between $12-20^{\circ} \mathrm{C}$ and during the rest of the year $16-30^{\circ} \mathrm{C}$. A major part of the study area is covered by dense tropical evergreen forests. Physiographically, the study region is bounded by hilly terrains to the north, east, and south. The study area is characterized by plain lands formed by the alluviums of river Barak and its tributaries, with occasional small hillocks rising above the plains. 


\section{Geological Background}

The Assam-Arakan Fold Belt (AAFB), a typical fold and thrust belt is located at the front of the Indo-Burma Ranges. The basin is bounded to the north by E-W trending Dauki Fault, to the east by N-S trending Kaladan Fault and towards the west by the undeformed foreland of Bengal Basin. The basin was thought to be developed as a result of the eastward subduction of the Indian Plate under the Burmese Plate (Angelier and Baruah 2009). Being located in the collisional zone, the basin has been subjected to intense tectonic disturbances and is characterized by a number of structural elements like folds, faults, and thrusts. In the study area, long narrow north-south trending anticlines are seen to be present with their intervening broad synclines (Ganguly 1983, 1993). The anticlines are dissected by several cross faults limiting the structures (Khar et al. 1984). The surface geological map of the study area is presented in Fig. 2.

The basin comprises thick clastic sediment deposited under marine to continental environments and ranges in age from Paleocene to Recent. The generalized stratigraphic succession of the basin is shown in Table 1. The sedimentary sequence appears to thicken towards the south and east (Chakravorty et al. 2011). Several exploratory wells for hydrocarbons have been drilled in the basin, but the complete stratigraphic succession has not been penetrated. Jenam formation of Barail group is the oldest stratigraphic unit encountered in the basin (Chatterjee et al. 2006). Surma and Tipam Group of sediments belonging to the Mio-Pliocene age are extensively exposed to the anticlinal structures in the basin (Ganguly 1993). A large part covering the plain areas of the study area is covered with alluviums.

\section{Petroleum system}

The presence of numerous oil and gas seepages throughout the basin authenticates the existence of an adequate petroleum system. The basin is one of the oldest explored petroliferous basins of India. Presently, the AAFB basin is classified as Category-I (proven commercially productive) basin in the hydrocarbon map of India (Biswas 2012). The thick dark grey organic carbon-rich shales of Barail Formation (Oligocene) and Lower and Middle Bhuban shales (Lower Miocene) of Surma Group are considered to be the source rock of petroleum in the basin (Uniyal et al. 1995; Biswas 2012). Well sorted, porous and permeable sandstone facies of Tipam, Bokabil, and Bhuban Formations act as excellent reservoirs. Thick impervious clays and shales of Surma and Tipam Groups serve as good seal rocks for the reservoirs (Biswas 2012). Both structural and stratigraphic traps dominate in the basin. The structural trap comprises of the anticlinal structures, while sandstone facies sandwiched between shales act as stratigraphic traps. Dissection of the anticlinal structures by faults often limits the extent of the reservoirs in the basin.

\section{Materials And Analytical Methods}

Fieldwork and sampling

Due to heavy rainfall in most of the year, the fieldwork was conducted during the short dry season in the study area to collect near-surface samples. Sediment samples were collected from shallow depths by manual digging. Due care was taken to avoid contamination and root zones of plants. A total of 57 sediment samples were collected in the field. The samples were then packed in air-tight polythene bags to avoid any degradation. The presence of hydrocarbon microseepages in the samples was established by the occurrence of the anomalous amount of lighter hydrocarbons (ethane to pentane) by extracting the adsorbed gases in the samples. Out of the total samples, only selective numbers of representative specimens were used for spectroscopic and geochemical studies.

\section{Reflectance spectroscopy}

Reflectance spectroscopy in the ultra-violet -visible-near infrared and short-wave infrared (UV-VNIR-SWIR) in the interval 250-2500 nm was carried out to identify and quantify constituent minerals in the samples. The field-collected samples were air-dried, pulverized to micron level in an agate mortar and pestle, and then sieved appropriately to separate any organic matter. The samples were analyzed in a spectrophotometer of Agilent Cary 5000 having a Tungstenhalogen and deuterium light source. The diffuse reflectance values were measured at $1 \mathrm{~nm}$ interval of wavelength. The minerals were identified by their characteristics absorption features. The quantitative abundance of the minerals was attempted with the help of analysis of the continuum removed reflectance spectra. The spectra of the standard minerals for the identification of the minerals were taken from the USGS spectral library.

X-ray diffraction (XRD)

As the collected samples were fine-grained sediments, optical microscopy was not very much helpful in the identification of the constituent mineral phases. XRD is considered as the most reliable and powerful tool for the identification of minerals in fine-grained rocks and sediments. The XRD was carried out to validate and correlate the reflectance spectroscopic results. The samples were first air-dried, ground to powder level with a mortar and pestle, homogenized and then sieved to filter out any undesirable particles. The samples were mounted in random orientation to identify all constituent minerals and their crystal planes. The specimens were analyzed in an XPERT-PRO X-ray diffractometer system using a Cu Ka X-rays $(\lambda=0.15406 \mathrm{~nm})$ over the $2 \theta$ range from 4.5 to 101 degrees in the steps of $0.0170(2 \theta)$ degree in continuous scanning mode at room temperature. The generated XRD data were processed and analyzed using the X'Pert High Score Plus software. The identification of minerals was carried out manually by matching with the published ICDD cards. Considering the complexities involved in the quantitative analysis of the XRD data, only qualitative analysis was carried out.

X-ray fluorescence (XRF) study

XRF spectrometry is the most extensively used precise analytical procedure in geochemistry for the determination of major and trace element concentrations (Rollinson 1993). The XRF analysis was carried out to quantify the major element oxide concentrations in the samples. The abundance of eleven major oxides, including $\mathrm{SiO}_{2}, \mathrm{Al}_{2} \mathrm{O}_{3}, \mathrm{Fe}_{2} \mathrm{O}_{3}$ (Total), $\mathrm{MgO}, \mathrm{CaO}, \mathrm{MnO}, \mathrm{TiO}_{2}, \mathrm{Na}_{2} \mathrm{O}, \mathrm{K}_{2} \mathrm{O}, \mathrm{P}_{2} \mathrm{O}_{5}$ and $\mathrm{LOI}$ (loss on ignition) were determined. To prepare the samples for XRF 
analysis, the samples were first air-dried, sieved ( $<2 \mathrm{~mm}$ ), and then ground to fine particle size (powder level). The powered samples were mixed with the binding agents (cellulose) and then palletized with a hydraulic press in stainless steel set by applying the optimum amount of pressure. Due care was taken during the sample preparation process to avoid sample to sample cross-contamination. The pallets were physically checked thoroughly for any cracks or voids before inserting them into the XRF spectrometer.

Inductively coupled plasma emission - mass spectrometry (ICP-MS) study

ICP-MS is a relatively new tool for the detection of trace element concentration in rocks/sediments. It is becoming increasingly accepted for its precise detection limit and for a wide range of trace elements within a short time (Rollinson 1993). This study was carried out to determine the concentrations of trace elements, including REEs. The concentrations of Li, Be, V, Cr, Co, Ni, Cu, Zn, Ga, Se, Rb, Sr, Pb, Bi, Cd, Cs, Zr, Nb, Mo, Ge, Ta, Sc, Y, and the REEs were determined. For the ICP-MS analysis, finely powdered samples were used.

\section{Results}

\section{Reflectance spectroscopy}

Three groups of minerals predominantly present in the hydrocarbon microseepage environments were attempted to identify by reflectance spectroscopy. These were: ferric iron oxides, clay minerals, and carbonate minerals. The most common ferric iron oxides in sediments are hematite and goethite. Hematite shows three distinct absorption bands at 520,650, and $880 \mathrm{~nm}$ (Clark 1999; Viscarra Rossel et al. 2010). Goethite exhibits weaker absorptions at 420, 480, 600, and $1700 \mathrm{~nm}$ and a strong absorption near $920 \mathrm{~nm}$ (Zheng et al. 2016). Among the clay minerals, kaolinite, montmorillonite, illite, vermiculite, and chlorite are the common clay minerals in the hydrocarbon microseepage environments. Clay minerals exhibit diagnostic absorption features near $1400 \mathrm{~nm}$ (caused by $\mathrm{OH}$ overtones), $1900 \mathrm{~nm}$ (overtones caused by water molecules), $2200 \mathrm{~nm}$ (due to Al-OH combination tones) and some weaker absorptions in the 2300$2500 \mathrm{~nm}$ range due to presence of Fe- or Mg-OH (Clark 1999; Zhao et al. 2018; Fang et al. 2018). Carbonate minerals show spectral characteristics absorption near 2350 and $2500 \mathrm{~nm}$ (Hunt and Salisbury, 1971).

The spectra of the sediments from both the hydrocarbon microseepage affected as well as unaffected areas show characteristics absorptions near 480 nm, $920 \mathrm{~nm}, 1400 \mathrm{~nm}, 1900 \mathrm{~nm}, 2200 \mathrm{~nm}, 2340 \mathrm{~nm}$, and $2440 \mathrm{~nm}$ (Fig. 3). The absorptions near 480 and 920 nm are characteristics of ferric iron minerals. It is observed that the reflectance spectra of fine-grained goethite (ID: MPCMA2-B of USGS Spectral Library) perfectly matches with the spectra of the samples in the ferric iron absorption wavelengths (Fig. 3). The shallow and asymmetric shape of the absorption feature in the interval $800-1000 \mathrm{~nm}$ indicates that the goethite is fine-grained non-crystalline in nature and mostly occur as grain coatings (Sheldon and Tabor 2009).

The characteristics absorption features at $1400 \mathrm{~nm}, 1900 \mathrm{~nm}, 2200 \mathrm{~nm}$ wavelength indicate the presence of clay minerals. The presence of kaolinite is ruled out by the absence of its characteristics spectral doublets near 2160 and $2210 \mathrm{~nm}$ (Fang et al. 2018) in the samples. Also, the absorption features characteristics of montmorillonite, vermiculite, and chlorite do not match with any of the spectra of the samples implying their absence in the samples. The characteristics prominent absorption at $1400 \mathrm{~nm}, 1900 \mathrm{~nm}, 2205 \mathrm{~nm}$, and the two weaker absorptions near $2340 \mathrm{~nm}$ and $2440 \mathrm{~nm}$ indicate that the clay minerals are predominantly composed of illite. The reflectance spectrum of illite with sample ID: IL 101 of USGS Spectral Library perfectly matches with the clay absorption features of the samples (Fig. 3). In the spectra of the sediments, absorption features are observed near $2350 \mathrm{~nm}$, indicating the presence of carbonate minerals, but the absorption feature also coincides with the $2340 \mathrm{~nm}$ absorption of illite. Also, the absorption at $2350 \mathrm{~nm}$ is not very deep, indicating that the carbonates in the sediments are of very low abundance.

The abundance of minerals was attempted by analyzing the continuum removed (CR) spectral curves of the samples. Continuum removal technique is one of the most efficient methods of determining the abundance of minerals and is considered as a feasible substitute for chemical statistical methods in mineralogy studies (Gomez et al. 2008; Viscarra Rossel et al. 2009). The technique generates a hull of boundary points using the local maxima (Gomez et al. 2008). It removes the background noise and highlights the particular absorption feature (Clark and Roush 1984). The strength and depth of the characteristic absorption feature of a mineral on the whole rock reflectance curve show the abundance of the mineral: the more profound the absorption feature, the more mineral is present in the rock sample (Clark 1999). The band depth (BD) at the characteristic absorption wavelength of a mineral was calculated by subtracting the continuum removed reflectance value from 1 (Viscarra Rossel et al. 2009) and was used as a measure of the mineral abundance. The characteristics absorption wavelength for goethite was taken as $941 \mathrm{~nm}$, and for illite at $2205 \mathrm{~nm}$ in the continuum removal curves (Fig. 4). As seen in Fig. 4, the continuum removed spectra of fine-grained goethite standard (MPCMA2-B) of the USGS spectral library, also exhibit absorption at the 2205 nm band wavelength. Thus, it is evident that the presence of goethite influences the band depth at $2205 \mathrm{~nm}$ for illite. Assuming a linear mixing model in the whole rock, the actual band depth of illite at $2205 \mathrm{~nm}$ was calculated by subtracting the band depth contribution of goethite from the gross band depth at $2205 \mathrm{~nm}$. The $\mathrm{CR}$ band depth calculation shows that the average CR band depth of goethite at $941 \mathrm{~nm}$ is lower (0.0227) in the hydrocarbon microseepage bearing sediments than that of the hydrocarbon non-anomalous sediments (0.0280). Again, it is also observed that the average CR band depth of illite at $2205 \mathrm{~nm}$ is higher (0.03128) for samples from microseepage bearing areas than that of the hydrocarbon unaffected sediments (0.0265). Thus, it is evident that the average content of ferric iron mineral is lower, and the average clay content is higher in the hydrocarbon microseepage bearing sediments in comparison to the hydrocarbon unaffected sediments.

\section{XRD Studies}

The X-ray diffractograms of the sediment samples from both the hydrocarbon affected and unaffected areas show prominent peaks for quartz, illite, muscovite, and feldspar. Illite is identified from the prominent peaks near $10^{\circ} \mathrm{A}, 4.48^{\circ} \mathrm{A}$, and $3.33^{0} \mathrm{~A} \mathrm{~d}$-spacings (Fig. 5). The peaks at $4.48^{0} \mathrm{~A}$ and $3.33^{\circ} \mathrm{A}$ of illite are, however, observed to be coincided with peaks of muscovite and quartz. It is, therefore, the XRD studies of the samples strongly support the spectroscopic 
observations. However, It is to be noted that though the sediments contain goethite as major ferric iron oxide as revealed by the spectroscopic studies, the prominent peak of goethite at 4.18A is absent in the X-Ray diffractograms. This is due to the fact that the goethites occur as a fine-grained coating around the constituent grains, which are opaque to XRD (Swayze et al. 2000). The X-ray diffractograms of the samples also lacked prominent peaks characteristics of carbonate minerals, indicating very low abundances of these minerals supporting the spectroscopic observations.

\section{XRF Studies}

Selective specimens were analyzed for XRF studies from hydrocarbon affected and unaffected areas. The average and median concentrations of the major element oxides are shown in Table.2. The table shows that the average concentrations of $\mathrm{Al}_{2} \mathrm{O}_{3}, \mathrm{Fe}_{2} \mathrm{O}_{3}$ (total), $\mathrm{CaO}, \mathrm{MnO}, \mathrm{K}_{2} \mathrm{O}$, and $\mathrm{P}_{2} \mathrm{O}_{5}$ are slightly higher, and $\mathrm{SiO}_{2}$ and $\mathrm{Na}_{2} \mathrm{O}$ content are slightly lower in the microseepage bearing sediments. It is observed that, though, the average $\mathrm{Al}_{2} \mathrm{O}_{3}$ content is slightly higher in the microseepage affected samples, the median value of $\mathrm{Al}_{2} \mathrm{O}_{3}$ is slightly higher in the microseepage unaffected sediments. Similarly, though the average $\mathrm{P}_{2} \mathrm{O}_{5}$ content is marginally higher in the hydrocarbon affected samples, the median values of $\mathrm{P}_{2} \mathrm{O}_{5}$ are the same in both the samples. The following geochemical indices were determined on the major element oxide data of the samples to get a better understanding of the degree of alterations:

Chemical index of alteration (CIA) is the most commonly used index to quantify the degree of chemical weathering the sediments have undergone and is expressed as (Nesbitt and Young 1982):

$\mathrm{ClA}=\left\{\mathrm{Al} 2 \mathrm{O} 3 /\left(\mathrm{Al}_{2} \mathrm{O}_{3}+\mathrm{CaO}+\mathrm{Na}_{2} \mathrm{O}+\mathrm{K}_{2} \mathrm{O}\right)\right\} * 100$

High CIA values indicate washing out of the more mobile elements like $\mathrm{Ca}$, $\mathrm{Na}$, and $\mathrm{K}$ with respect to relatively immobile $\mathrm{Al}$ and thus represent high chemical weathering. The greatest CIA values (close to 100) correspond to kaolinite weathering, values between 75-90 represent illite, and for feldspars, it is 50 (Nesbitt and Young 1982; Fedo et al. 1995; Nadłonek and Bojakowska 2018). The average ClA value for the hydrocarbon affected sediments (85.89) is nearly the same as that of the hydrocarbon unaffected sediments (85.80). These CIA values fall in the advanced stage of weathering in the illite zone, reflecting that the major constituent of the sediments/sediments is illite. This is also supported by the spectroscopic studies, which indicated illite as major constituent clay mineral in the sediment samples.

The silicification index $(\mathrm{SI})$ is a measure of silica content and is defined as:

$\mathrm{SI}=\left[\mathrm{SiO}_{2} /\left(\mathrm{SiO}_{2}+\mathrm{Al}_{2} \mathrm{O}_{3}\right)\right] * 100$ (after Pirajno, 2009)

The higher values of SI indicate a higher amount of silica in the samples. It is observed that the average SI value is lower (72.76) for the microseepage affected samples in comparison to the microseepage unaffected samples (74.51). Thus, it is indirectly evident that some amount of silica has been depleted in the hydrocarbon microseepage induced sediments.

Alteration index (Al) is a measure of the degree of the alteration as suggested by Ishikawa et al. (1976) and is measured by

$\mathrm{Al}=\left\{\left(\mathrm{K}_{2} \mathrm{O}+\mathrm{MgO}\right) /\left(\mathrm{K}_{2} \mathrm{O}+\mathrm{MgO}+\mathrm{Na}_{2} \mathrm{O}+\mathrm{CaO}\right)\right\} * 100$

The alteration index calculation reveals that the average Al for the hydrocarbon induced sediments is higher (83.14) than that of the hydrocarbon unaffected sediments (81.29). Therefore, although the average bulk compositions of the sediments are similar, the different alteration indices indicate a higher degree of alteration in the hydrocarbon microseepage bearing sediments.

A new geochemical index to quantify the hydrocarbon microseepage related alterations termed as Microseepage-Induced Alteration Index (MIAI) has been introduced by Asadzadeh et al. (2020). The MIAl is defined as under:

$\mathrm{MIAI}=\left\{\left(\mathrm{CaO}+\mathrm{K}_{2} \mathrm{O}\right) /\left(\mathrm{Na}_{2} \mathrm{O}+\mathrm{K}_{2} \mathrm{O}+\mathrm{CaO}+\mathrm{MgO}\right)\right\}^{*} 100$

The MIAI calculation shows that average MIAI values are higher (54.95) in the microseepage affected sediments with respect to the hydrocarbon microseepage unaffected sediments (52.54). This indicates that the hydrocarbon microseepage affected sediments have undergone more alteration than that of the hydrocarbon unaffected ones. The results, therefore, prove that the MIAI is an efficient index in differentiating hydrocarbon microseepage induced alterations in sediments.

\section{Trace element (excluding REEs) studies}

Limited numbers of specimens were analyzed by inductively coupled plasma-mass spectrometry (ICP-MS). The result of the trace elements (excluding REEs) is shown in Table 3. The distribution of the average trace element concentrations reflects that the hydrocarbon-bearing sediments are enriched in average Be, $\mathrm{V}, \mathrm{Cu}, \mathrm{Zn}, \mathrm{Ga}, \mathrm{Zr}$, and $\mathrm{Mo}$ and are depleted in $\mathrm{Li}, \mathrm{Cr}, \mathrm{Co}, \mathrm{Ni}, \mathrm{Rb}, \mathrm{Sr}, \mathrm{Sc}$, and Y.

\section{REE studies}

The REE values of each specimen were normalized with respect to Post-Archaean Average Australian Sedimentary rock (PAAS) (McLennan I989) values. The average normalized value of the REEs for the specimens are shown in Table 4. The table indicates that the average REE values are higher in the hydrocarbon unaffected sediments. The PAAS normalized REE plots for the samples are shown in Fig. 6 . The REE patterns show that all the sediment samples exhibit positive Eu positive anomalies. These results, in general, also support the observations by Asadzadeh et al. (2020).

\section{Discussion}


Reflectance spectroscopic studies show that hydrocarbon microseepage bearing sediments are deficient in ferric iron mineral content in comparison to the hydrocarbon unaffected sediments. On the other hand, hydrocarbon affected sediments are enriched in clay content in relation to the non-hydrocarbon bearing sediments. Both of these observations suggest that microseepage bearing sediments have undergone a higher degree of bleaching of ferric iron minerals and alteration of other minerals (feldspar and mica) to clay minerals. The bleaching of ferric iron minerals and an increase in clay content may be attributed to the effects of hydrocarbon microseepages. The spectroscopic studies also reveal that both the hydrocarbon affected and unaffected samples have low abundance of carbonate minerals which may be due to the facts that the parent rocks being mostly shales and sandstones do not contain any appreciable amount of $\mathrm{Ca}$ or the carbonates formed in the microseepage environment are easily dissolved in the abundant surface and groundwater in the acidic conditions and are mobilized away from the hydrocarbon microseepage systems. The spectroscopic results, therefore, indicate that the alteration effects of hydrocarbon microseepages are also evident in the high rainfall areas.

The qualitative XRD studies strongly support the spectroscopic observations on the presence of illite and low abundance of carbonate minerals. The lack of prominent peaks of goethite in the X-ray diffractograms is interpreted in terms of their occurrences as fine-grained coatings which are opaques to XRD. The lack of prominent peaks of carbonate minerals in the XRD points out the low abundance of carbonates in the sediments supporting the spectroscopic observations.

The major element oxide analysis by XRF reveals that except for $\mathrm{SiO}_{2}$, the distributions of other oxides are not significantly different between hydrocarbon microseepage affected and unaffected samples. The similar bulk compositions of the sediments indicate that both the microseepage affected and unaffected sediments are derived from the same provenance/precursor rocks. The depletion of $\mathrm{SiO}_{2}$ in the hydrocarbon-bearing sediments may be indicative of silica leaching from the microseepage system. Again, as the $\mathrm{Fe}_{2} \mathrm{O}_{3}$ value represents a total of ferric and ferrous iron oxide concentration, no definite conclusions can be drawn from the $\mathrm{Fe}_{2} \mathrm{O}_{3}$ distribution. The slight abundances of $\mathrm{K}_{2} \mathrm{O}$ and $\mathrm{CaO}$ in the hydrocarbon-induced samples are in consistent with the current study by Asadzadeh et al. (2020). Among the different geochemical indices, the average alteration index (Al) is higher (83.14) in the hydrocarbon induced sediments in comparison to the hydrocarbon unaffected ones (81.29). This indicates that the hydrocarbon affected areas have undergone a higher degree of alteration. Lower silicification index (SI) value in the hydrocarbon induced sediments (72.76) with respect to the non-hydrocarbon ones (74.51) show that these sediments have been subjected to silica leaching. The nearly same values of CIA ( 85) in the hydrocarbon affected and unaffected sediments indicate that the areas have undergone same degree of weathering. The higher average MIAl value in the hydrocarbon induced samples clearly indicates a higher degree of hydrocarbon induced alteration effects. Thus, Al, SI, and MIAl can effectively differentiate between the hydrocarbon affected and unaffected sediments though their differences are small. The small difference in geochemical indices may be attributed to the presence of abundant surface and groundwater in the study area, which mobilizes the alteration products from the hydrocarbon microseepage systems.

Hydrocarbon affected sediments are generally enriched in trace metals like $\mathrm{V}, \mathrm{Cr}, \mathrm{Zn}, \mathrm{Cu}, \mathrm{Co}, \mathrm{Mo}, \mathrm{Pb}$ in response to the reducing environment created by microseepages (Duchscherer, 1984; Schumacher 1996). The trace element distribution pattern of the samples reflects that the hydrocarbon-bearing sediments are enriched in average $\mathrm{Be}, \mathrm{V}, \mathrm{Cu}, \mathrm{Zn}, \mathrm{Ga}, \mathrm{Zr}$, and $\mathrm{Mo}$ and are depleted in $\mathrm{Li}, \mathrm{Cr}, \mathrm{Co}, \mathrm{Ni}, \mathrm{Rb}, \mathrm{Sr}, \mathrm{Sc}$, and Y. However, the median values of $\mathrm{Ni}$, Rb, and Sc are slightly higher, and the median value of $\mathrm{Zn}$ is lower in the microseepage affected sediments. Thus, the results, in general, are in conformity with the trace element distribution of the hydrocarbon microseepage system. The distribution of the trace elements revealed in the present study also supports the studies by Petrovic et al. (2012) and Asadzadeh et al. (2020).

The PAAS normalized REE distribution patterns are more or less similar in both the specimens from hydrocarbon affected and unaffected areas. However, the hydrocarbon affected sediments are more depleted in the REEs in comparison to the hydrocarbon unaffected ones, which may be due to the higher degree of alterations, the hydrocarbon affected sediments have undergone. Both the samples from hydrocarbon affected and unaffected areas show Eu positive anomalies. The REEs are good indicators of the provenance because they are insoluble in water and are chiefly transported as particulate matter (Rollinson 1993). The similar patterns of the REEs indicate that the sediments are derived from the same provenance. The study, thus, indicates that hydrocarbon microseepage affected and unaffected sediments cannot be differentiated effectively on the basis of REE patterns. The consistent patterns of the REEs also support the current study by Asadzadeh et al. (2020).

\section{Conclusions}

The reflectance spectroscopy on the hydrocarbon microseepage-induced sediments in the study area indicates that the two most important alteration characteristics-bleaching of red beds and the increase in clay content, are clearly evident. The geochemical indices like Al, SI, and MIAI also reflect that the hydrocarbon induced sediments have undergone a little higher degree of alterations. The hydrocarbon affected sediments are also enriched in some trace elements characteristics of hydrocarbon microseepage environments. Though, the PAAS normalized REE patterns are similar for both the sediments, hydrocarbon affected sediments are slightly depleted in the average normalized REE values. The study, therefore, shows that alteration characteristics of hydrocarbon microseepages are evident in the high precipitation areas also. However, the alteration effects in high rainfall areas are not as pronounced as that of the arid to semi-arid climatic regions due to the fact that the abundant surface and groundwater mobilizes minerals and elements from the hydrocarboninduced microseepage systems and tends to homogenize their distributions in the sediments.

\section{Declarations}

\section{Availability of data and materials}

All data presented in the text of the article are fully available without restriction from authors upon request.

\section{Competing interests}


The authors declare that they have no competing interests.

\section{Funding}

The authors received no financial support for the research.

\section{Authors' contributions}

SG and PD conceived, designed and carried out the research. DM supervised the research work. SG drafted the manuscript. All authors contributed to data interpretation, discussion, and revision of the manuscript.

\section{Acknowledgments}

The authors are grateful to the Indian Institute of Technology (Indian School of Mines), Dhanbad, India and the Indian Institute of Remote Sensing, Dehradun, India for providing infrastructural facilities for carrying out the studies. The authors are also thankful to the USGS, from where the Landsat 8 images and reflectance spectra of the standard minerals were freely downloaded. The views expressed in the article are the authors' own and do not represent the organizations they belong to.

\section{References}

1. Angelier J, Baruah S (2009) Seismotectonics in Northeast India: a stress analysis of focal mechanism solutions of earthquakes and its kinematic implications. Geophys J Int 178:303-326. doi:10.1111/j.1365-246X.2009.04107.x

2. Asadzadeh S, de Souza Filho CR (2017) Spectral remote sensing for onshore seepage characterization: A critical overview. Earth Sci Rev 168:48-72. http://dx.doi.org/10.1016/j.earscirev.2017.03.004

3. Asadzadeh S, de Souza Filho CR (2020) Characterization of microseepage-induced diagenetic changes in the Upper Red Formation, Qom region, Iran. Part I: Outcrop, geochemical, and remote sensing studies. Mar Pet Geol 113:104149. https://doi.org/10.1016/j.marpetgeo.2019.104149

4. Biswas SK (2012) Status of petroleum exploration in India. Proc Ind Natn Sci Acad 78:3:475-494

5. Chakravorty D, Gupta S, Shyam R, Bandari A (2011) A re-look into exploration strategy of Lower Bhuban play in Eastern Tripura, India - A case study. The 2nd South Asian Geoscience Conference and Exhibition, GEO India, Greater Noida, New Delhi, India

6. Chandrasekaran P, Choudhury S, Yadagiri K, Sanyal A, Reddy PK (2006) An approach for quantification of geological risk. 3rd International Conference, APG, India

7. Chatterjee SM, Deb A, Rao CV, Reddy PK, Sanyal A, Yadagiri K (2006) Triangle zone geometry in Cachar thrust-fold belt, India. SEG New Orleans Annu Meet $76: 1118-1122$

8. Clark RN (1999) Spectroscopy of rocks and minerals, and principles of spectroscopy. In: Rencz N (ed) Remote Sensing for the Earth Sciences: Manual of Remote Sensing. John Wiley \& Sons, New York, pp 3-52

9. Clark RN, Roush TL (1984) Reflectance spectroscopy: quantitative analysis techniques for remote sensing applications. J Geophys Res Solid Earth 89:B7:6329-6340

10. Donovan TJ (1974) Petroleum microseepage at Cement, Oklahoma-evidence and mechanisms. AAPG Bull 58:429-446

11. Duchscherer W (1984) Geochemical hydrocarbon prospecting with case histories: Tulsa, Oklahoma, PennWell Publishing:196

12. Etiope G (2015) Natural gas seepage: The Earth's hydrocarbon degassing. Springer International Publishing, Switzerland

13. Fang Q, Hong H, Zhao L et al (2018) Visible and near-infrared reflectance spectroscopy for investigating soil mineralogy: A review. Hindawi Jour Spectroscopy. https://doi.org/10.1155/2018/3168974

14. Fedo CM, Nesbitt HW, Young GM (1995) Unravelling the effects of potassium metasomatism in sedimentary rocks and paleosols, with implications for paleoweathering conditions and provenance. Geology 23:921-934

15. Ganguly S (1983) Geology and hydrocarbon prospects of Tertiary succession of Tripura-Cachar-Mizoram region. Petroleum Asia journal 1:105-109

16. Ganguly S (1993) Stratigraphy, sedimentation and hydrocarbon prospects of the Tertiary succession of Tripura and Cachar (Assam). Ind Jour Geol 65:3:145-180

17. Geological Survey of India (2009) Geology and mineral resources of Assam. Misc. Publication 30:IV:2(i)

18. Gomez C, Lagacherie P, Coulouma G (2008) Continuum removal versus PLSR method for clay and calcium carbonate content estimation from laboratory and airborne hyperspectral measurements. Geoderma 148:2:141-148

19. Hunt GR, Salisbury JW (1971) Visible and near-infrared spectra of minerals and rocks. Mod Geol 2:23-30

20. Ishikawa Y, Sawaguchi T, Iwaya S, Horiuchi M (1976) Delineation of prospecting targets for Kuroko deposits based on modes of volcanism of underlying dacite and alteration halos. Min Geol 26:105-117

21. Kamaraju AVVS (2010) Modeling concealed structures of Cachar fold belt integrating seismic, geologic and landsat imageries with special reference to Bhubandar field-Assam and Assam Arakan Fold belt, India. In: 8th biennial international conference \& exposition on petroleum geophysics, Hyderabad

22. Khar BM, Ganju JL (1984) Tectonic of Tripura folds - probable mechanics of folding and faulting. Petroleum Asia Journal 1:66-77

23. Link WK (1952) Significance of oil and gas seeps in world oil exploration. AAPG Bull 36(8):1505-1540 
24. Mazumder S, Adhikari K, Mitra DS, Mahapatra S, Pangtey KKS (2016) A neotectonic based geomorphic analysis using remote sensing data to delineate potential areas of hydrocarbon exploration: Cachar area, Assam. J Geol Soc India 88:1-11

25. McLennan SM (1989) Rare earth elements in sedimentary rocks. Influence of provenance and sedimentary processes. Rev Mineral 21:169-200

26. Nadłonek W, Bojakowska I (2018) Variability of chemical weathering indices in modern sediments of the Vistula and Odra Rivers (Poland). Applied Ecology Environmental Research 16(3):2453-2473. http://dx.doi.org/10.15666/aeer/1603_24532473

27. Nesbitt HW, Young GM (1982) Early Proterozoic climates and plate motions inferred from major element chemistry of lutites. Nature 299:715-717

28. Petrovic A, Khan SD, Thurmond A (2012) Integrated hyperspectral remote sensing, geochemical and isotopic studies for understanding hydrocarboninduced rock alterations. Mar Pet Geol 35:292-308

29. Pirajno F (2009) Hydrothermal Processes and Mineral Systems. Springer Science

30. Price LC (1986) A critical review and proposed working model of surface geochemical exploration. In: Davidson MJ (ed) Unconventional Methods in Exploration for Petroleum and Natural Gas. Southern Methodist University Press, Dallas, pp 245-304

31. Rollinson HR (1993) Using geochemical data: evaluation, presentation, interpretation. Ist ed. Longman Scientific \& Technical, UK

32. Saunders DF, Burson KR, Branch JF, Thompson CK (1993a) New method of aerial and surface radiometric prospecting for oil, gas. Oil Gas J 91:38:104109

33. Saunders DF, Burson KR, Thompson CK (1999) Model for hydrocarbon microseepage and related near-surface alterations. AAPG Bull 83(1):170-185

34. Schumacher D (1996) Hydrocarbon-induced alteration of soils and sediments. In: Schumacher D, Abrams MA (Eds.), Hydrocarbon Migration and Its Nearsurface Expression. Tulsa, USA. AAPG Memoir 66:71-89

35. Schumacher D (1999) Surface geochemical exploration for petroleum. In: Beaumont EA, Foster NH (eds), Treatise of Petroleum Geology/Handbook of Petroleum Geology: Exploring for Oil and Gas Traps. AAPG: 18-1-18-27

36. Segal DB, Ruth MD, Merin IS et al (1984) Correlation of remotely detected mineralogy with hydrocarbon production, Lisbon Valley, Utah. ERIM Proceedings of the International Symposium on Remote Sensing for Exploration Geology 273-292

37. Segal DB, Ruth MD, Merin IS (1986) Remote detection of anomalous mineralogy associated with hydrocarbon production, Lisbon Valley, Utah. The Mountain Geologist 23:2:51-62

38. Sheldon ND, Tabor NJ (2009) Quantitative paleoenvironmental and paleoclimatic reconstruction using paleosols. Earth Sci Rev 95(1-2):1-52

39. Swayze GA, Smith KS, Clark RN, Sutley SJ, Pearson RM, Vance JS, Hageman PL, Briggs PH, Meier AL, Singleton MJ, Roth S (2000) Using imaging spectroscopy to map acidic mine waste. Env Sci Tech 34:47-54

40. Tedesco SA (1995) Surface Geochemistry in Petroleum Exploration. Chapman and Hall, Inc, New York

41. Uniyal AK, Mittal AK, Dwivedi P, Chandra U, Benerji V, Dhawan R, Mathur M (1995) Genetic classification of Natural Gases of Tripura - Cachar, India. Proceeding of the 1st Int Pet Conf and Exbn Petrotech, New Delhi, India

42. Viscarra Rossel RA, Behrens T (2010) Using data mining to model and interpret soil diffuse reflectance spectra. Geoderma 158:1:46-54

43. Viscarra Rossel RA, Cattle SR, Ortega A, Fouad Y (2009) In situ measurements of soil colour, mineral composition and clay content by vis-NIR spectroscopy. Geoderma 150:3:253-266

44. Warren RK (2012) Near-surface resistivity for hydrocarbon detection. Lead Edge 31:10:1182-1191

45. Zhao L, Hong H, Liu J et al (2018) Assessing the utility of visible to-shortwave infrared reflectance spectroscopy for analysis of soil weathering intensity and paleoclimate reconstruction. Palaeogeogr Palaeoclimatol Palaeoecol 58:429-446

46. Zheng G, Jiao C, Zhou S, Shang G (2016) Analysis of soil chronosequence studies using reflectance spectroscopy. Int J Remote Sensing 37:8:1881-1901

\section{Tables}

Table 1: The generalized stratigraphic succession of the AAFB basin (after Chandrasekaran et al. 2006 and GSI, 2009). 


\begin{tabular}{|c|c|c|c|}
\hline Age & Group & Formation & Lithology \\
\hline \multirow[t]{2}{*}{ Recent } & & Alluvium & Sand, silt, clay, pebble or boulder deposit \\
\hline & & Dihing Formation & Pebble beds, clay, sandstone and conglomerate \\
\hline Pleistocene & & Dupitila Formation & Conglomerate, sandstone, mottled clay, coal beds and pebbles \\
\hline \multirow{2}{*}{ Pliocene } & Tipam Group & Gobindpur Formation & Mottled clays with subordinate sandstone. \\
\hline & & Tipam Sandstone Formation & Coarse to gritty ferruginous sandstone with minor clay/ shale \\
\hline \multirow{3}{*}{ Miocene } & Surma Group & Bokabil Formation & Dominantly shale/claystone with minor siltstone and sandstone. \\
\hline & & Upper Bhuban Formation & Predominantly arenaceous unit with minor shale. \\
\hline & & Middle Bhuban Formation & Dominantly argillaceous unit with occasional sandstone beds \\
\hline \multirow{3}{*}{ Oligocene } & & Lower Bhuban Formation & Dominantly sandstone with minor siltstone and shale. \\
\hline & Barail Group & Renji Formation & Thick bedded sandstone \\
\hline & & Jenam Formation & Shale or carbonaceous shale with subordinate sandstone \\
\hline & & Laisong Formation & Sandstone with minor shale \\
\hline Cretaceous to Eocene & Disang Group & Un-differentiated & Dark grey shale with thin sandstone \\
\hline Basement not exposed & & & \\
\hline
\end{tabular}

Table 2: Major element oxide analyses for hydrocarbon affected and hydrocarbon unaffected sediments.

\begin{tabular}{|c|c|c|c|c|c|c|c|c|c|c|c|}
\hline $\begin{array}{l}\text { Major element oxide } \\
\text { (wt \%) }\end{array}$ & & $\mathrm{SiO}_{2}$ & $\mathrm{Al}_{2} \mathrm{O}_{3}$ & $\mathrm{Fe}_{2} \mathrm{O}_{3}$ & $\mathrm{MgO}$ & $\mathrm{CaO}$ & Mno & $\mathrm{TiO}_{2}$ & $\mathrm{Na}_{2} \mathrm{O}$ & $\mathrm{K}_{2} \mathrm{O}$ & $\mathrm{P}_{2} \mathrm{O}_{5}$ \\
\hline \multirow[t]{2}{*}{ Microseepage affected } & Average & 58.6547 & 21.9515 & 5.722 & 1.5914 & 0.1369 & 0.0503 & 0.9265 & 0.7319 & 2.7004 & 0.0716 \\
\hline & Median & 58.382 & 22.049 & 6.088 & 1.528 & 0.137 & 0.02 & 0.929 & 0.722 & 2.75 & 0.058 \\
\hline \multirow[t]{2}{*}{ Microseepage unaffected } & Average & 60.8513 & 20.8785 & 5.4951 & 1.5432 & 0.1218 & 0.0228 & 0.9298 & 0.8044 & 2.4804 & 0.0591 \\
\hline & Median & 60.64 & 22.8645 & 5.231 & 1.5435 & 0.115 & 0.012 & 0.9385 & 0.816 & 2.5425 & 0.058 \\
\hline
\end{tabular}

Table 3: Trace elements analysis of samples from hydrocarbon-bearing and non-hydrocarbon bearing areas.

\begin{tabular}{|c|c|c|c|c|c|c|c|c|c|c|c|c|c|c|c|c|}
\hline \multicolumn{2}{|c|}{$\begin{array}{l}\text { Trace element } \\
\text { (conc. ppm) }\end{array}$} & $\mathrm{Li}$ & $\mathrm{Be}$ & V & $\mathrm{Cr}$ & Co & $\mathrm{Ni}$ & $\mathrm{Cu}$ & $Z n$ & $\mathrm{Ga}$ & $\mathrm{Se}$ & $\mathrm{Rb}$ & $\mathrm{Sr}$ & $\mathrm{Pb}$ & $\mathrm{Bi}$ & Cd \\
\hline \multirow{3}{*}{$\begin{array}{l}\mathrm{HC} \\
\text { affected }\end{array}$} & Average & 32.23 & 2.58 & 118.55 & 115.26 & 12.76 & 55.18 & 22.77 & 69.68 & 21.66 & 0.36 & 62.16 & 48.17 & 18.65 & 0.45 & 0.35 \\
\hline & Median & 33.43 & 2.68 & 120.86 & 118.67 & 12.33 & 57.57 & 23.34 & 65.39 & 22.36 & 0.32 & 69.07 & 57.53 & 19.44 & 0.45 & 0.15 \\
\hline & $\begin{array}{l}\text { Std. } \\
\text { Dev. }\end{array}$ & 6.17 & 0.37 & 26.56 & 21.22 & 1.89 & 10.01 & 4.40 & 13.24 & 4.56 & 0.10 & 34.84 & 26.36 & 7.11 & 0.15 & 0.43 \\
\hline \multirow{3}{*}{$\begin{array}{l}\mathrm{HC} \\
\text { unaffected }\end{array}$} & Average & 34.21 & 2.41 & 113.64 & 125.17 & 14.46 & 57.76 & 20.91 & 68.88 & 20.08 & 0.32 & 65.68 & 55.79 & 18.65 & 0.35 & 0.15 \\
\hline & Median & 35.97 & 2.73 & 115.59 & 124.65 & 13.08 & 55.24 & 22.52 & 76.27 & 21.76 & 0.28 & 62.34 & 58.06 & 19.55 & 0.36 & 0.13 \\
\hline & $\begin{array}{l}\text { Std. } \\
\text { Dev. }\end{array}$ & 10.68 & 0.67 & 36.00 & 27.08 & 5.33 & 20.97 & 6.67 & 20.83 & 5.52 & 0.22 & 19.00 & 12.71 & 7.21 & 0.13 & 0.04 \\
\hline
\end{tabular}

Table 4: PAAS normalized REE values of the hydrocarbon-affected and hydrocarbon unaffected sediments. 


\begin{tabular}{|c|c|c|c|c|c|c|c|c|c|c|c|c|c|c|c|}
\hline \multicolumn{2}{|c|}{$\begin{array}{l}\text { REE } \\
\text { (PAAS Normalized values) }\end{array}$} & $\mathrm{La}$ & $\mathrm{Ce}$ & $\operatorname{Pr}$ & Nd & Sm & Eu & Gd & $\mathrm{Tb}$ & Dy & Ho & $\mathrm{Er}$ & $\mathrm{Tm}$ & $\mathrm{Yb}$ & Lu \\
\hline \multirow[t]{3}{*}{$\mathrm{HC}$ affected } & Average & 0.546 & 0.637 & 0.615 & 0.600 & 0.777 & 0.898 & 0.902 & 0.801 & 0.743 & 0.684 & 0.732 & 0.704 & 0.675 & 0.634 \\
\hline & Median & 0.497 & 0.573 & 0.614 & 0.593 & 0.755 & 0.846 & 0.846 & 0.747 & 0.718 & 0.621 & 0.702 & 0.676 & 0.650 & 0.613 \\
\hline & Std. Dev. & 0.280 & 0.235 & 0.278 & 0.273 & 0.334 & 0.321 & 0.356 & 0.298 & 0.231 & 0.213 & 0.190 & 0.163 & 0.145 & 0.134 \\
\hline \multirow[t]{3}{*}{$\mathrm{HC}$ unaffected } & Average & 0.723 & 0.737 & 0.746 & 0.727 & 0.906 & 1.039 & 1.051 & 0.872 & 0.777 & 0.737 & 0.754 & 0.728 & 0.687 & 0.649 \\
\hline & Median & 0.671 & 0.728 & 0.716 & 0.696 & 0.894 & 0.994 & 1.038 & 0.877 & 0.780 & 0.716 & 0.778 & 0.724 & 0.714 & 0.670 \\
\hline & Std. Dev. & 0.201 & 0.240 & 0.204 & 0.192 & 0.254 & 0.303 & 0.307 & 0.252 & 0.214 & 0.193 & 0.197 & 0.196 & 0.169 & 0.157 \\
\hline
\end{tabular}

\section{Figures}

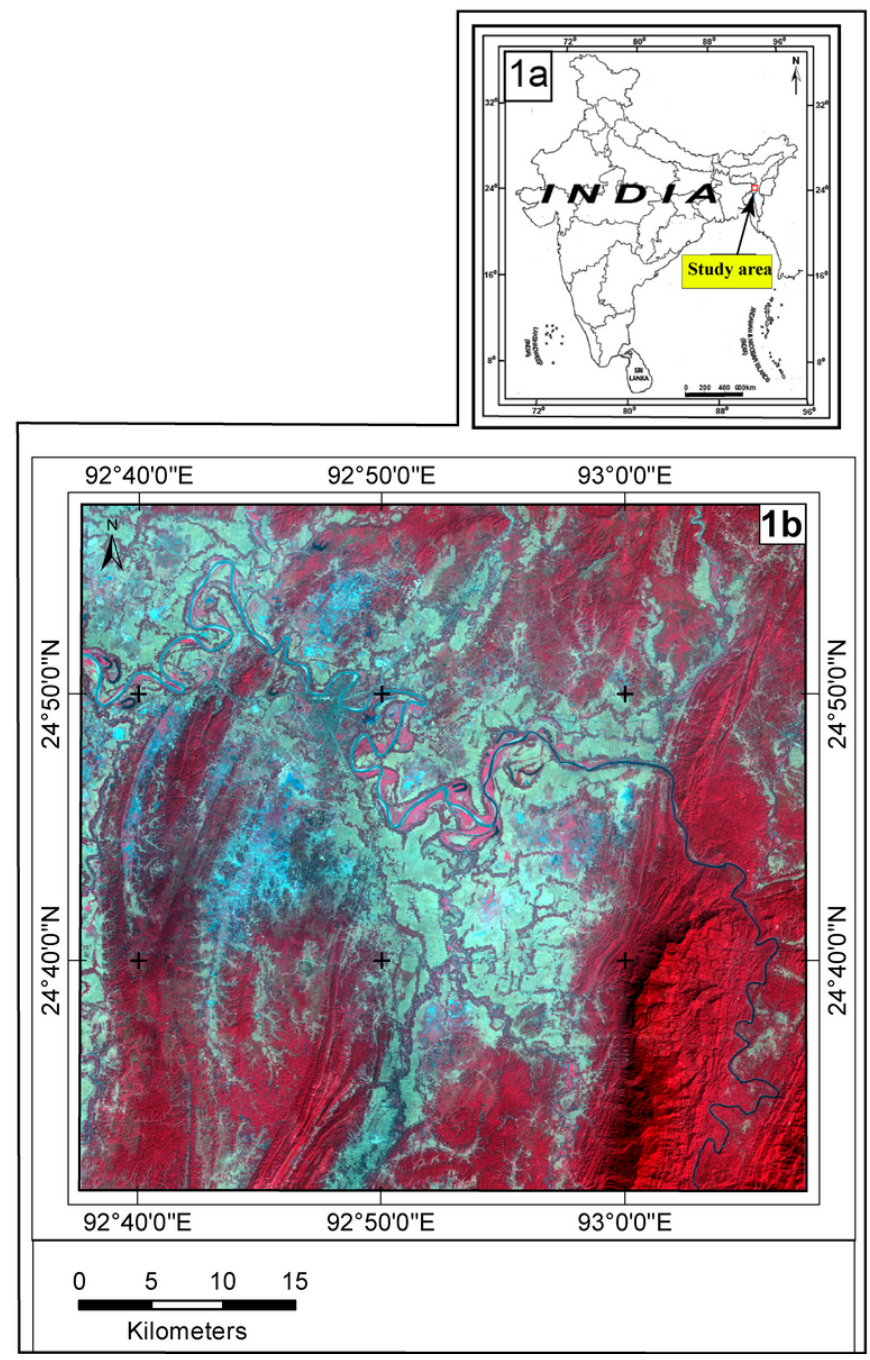

Figure 1

a. Location map of the study area. b. False colour composite (FCC) map of the study area formed by Landsat 8 bands 5-4-3 in RGB space. 


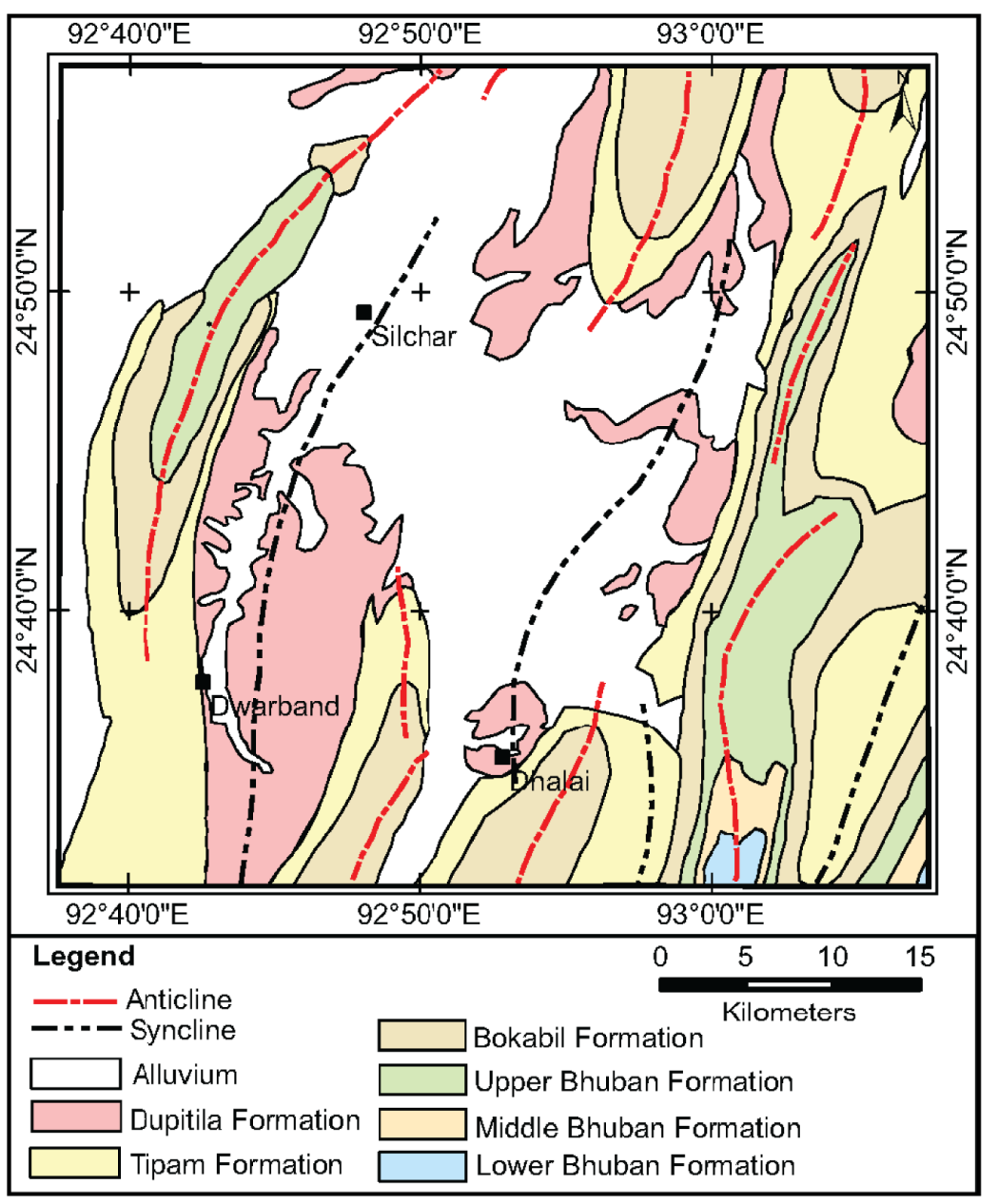

Figure 2

Surface geological map of the study area (adapted from Mazumder et al. 2016; Kamaraju 2010). 


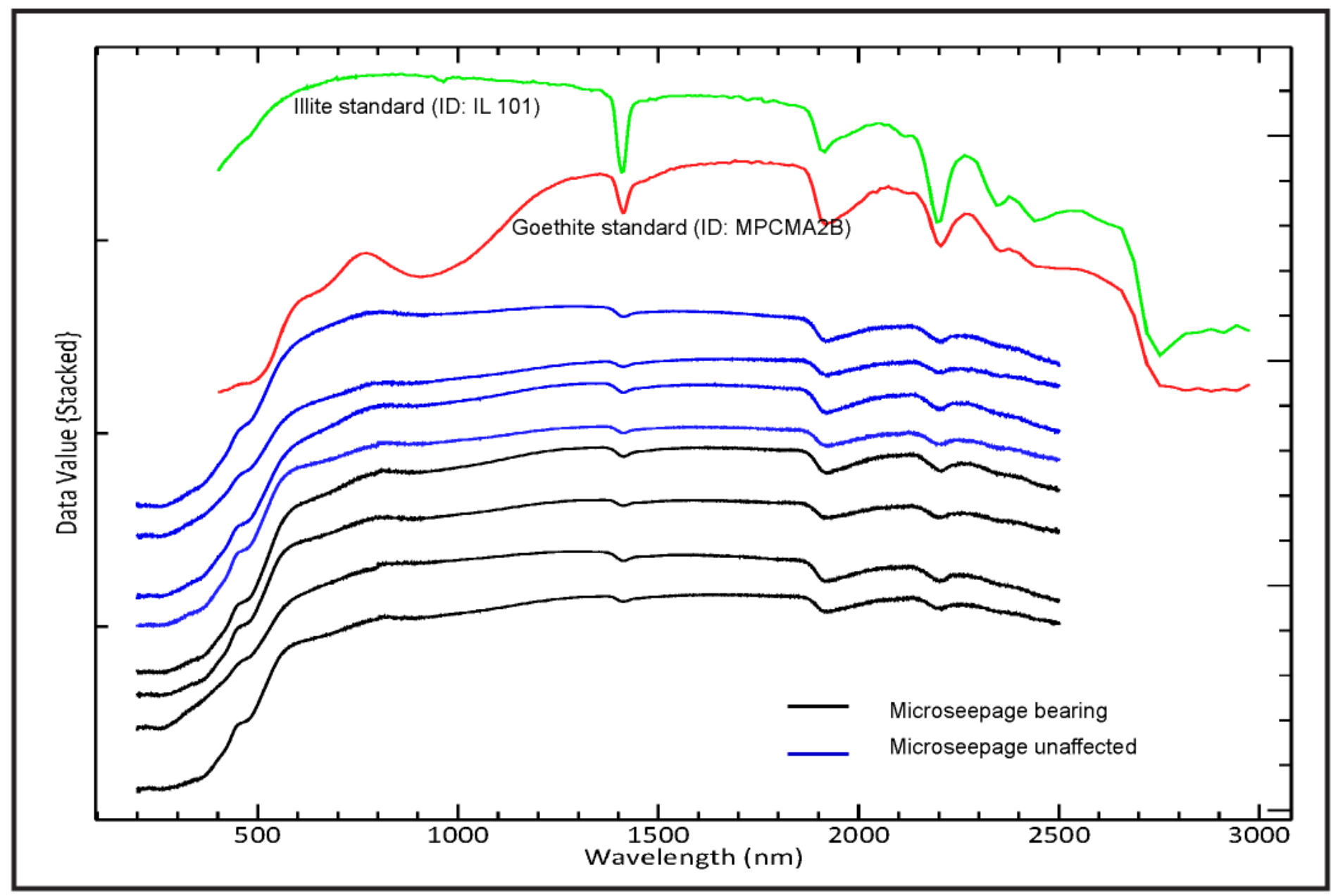

Figure 3

Reflectance spectra of hydrocarbon microseepage- affected and unaffected sediments. 


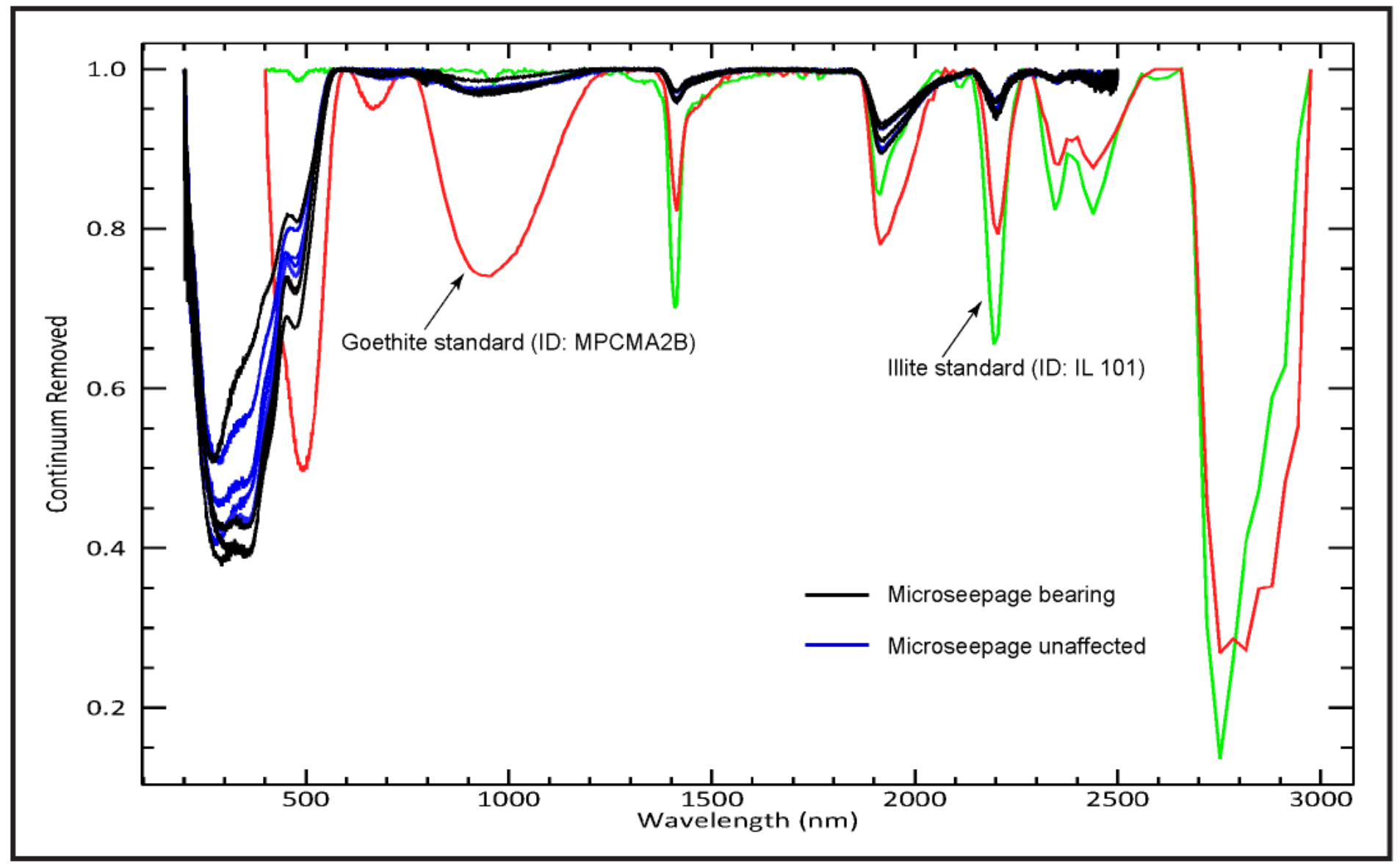

Figure 4

Continuum-removed reflectance spectra of hydrocarbon microseepage- affected and unaffected sediments. 


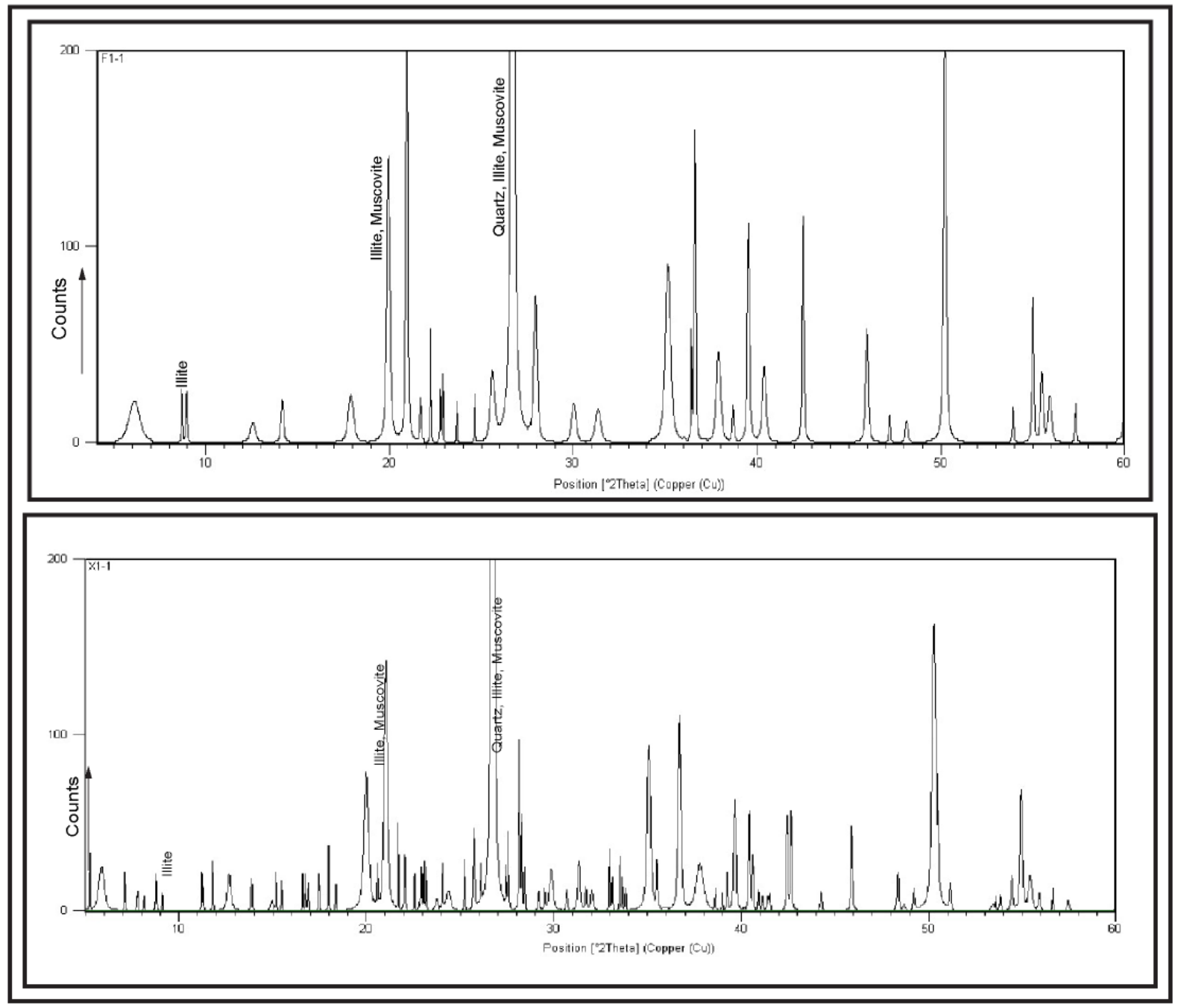

Figure 5

Typical X-ray diffraction patterns of the hydrocarbon microseepage-affected (upper) and unaffected (lower) sediments. 


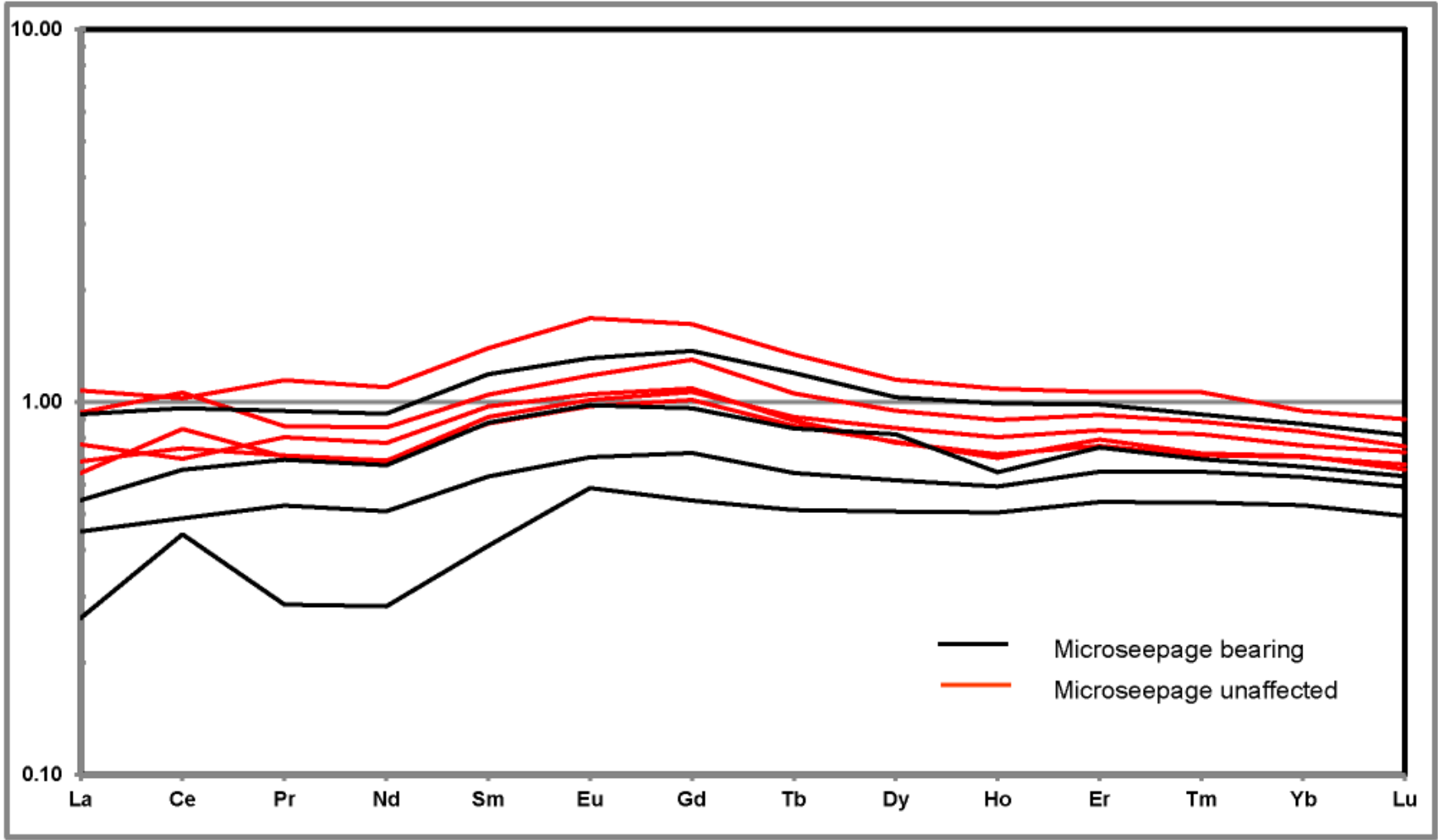

Figure 6

PAAS normalized REE distribution patterns of the hydrocarbon bearing and non-bearing sediments. 